\title{
Pemodelan Transpor Sedimen Pantai Kualo Kota Bengkulu
}

\author{
Besperi $^{1)}$, Gusta Gunawan ${ }^{1)}$, Tessa Dwi Utari ${ }^{1)}$ \\ ${ }^{1)}$ Fakultas Teknik Universitas Bengkulu \\ Jl. W. R. Supratman, Kandang Limun, Kota Bengkulu 38371, \\ Corresponding author: besperi@unib.ac.id
}

\begin{abstract}
Abstrak
Provinsi Bengkulu merupakan salah satu daerah dengan pantai terpanjang di Indonesia. Secara umum keadaan pantai di Bengkulu telah banyak mengalami kerusakan berupa abrasi dan sedimentasi. Perubahan garis pantai disebabkan oleh faktor alam dan/atau faktor manusia. Secara geografis, Pantai Kualo terletak di bagian Barat Pulau Sumatera yang berhadapan langsung dengan Samudera Hindia. Ini berarti, seluruh tepian barat merupakan daerah laut lepas dengan sedikit pulau yang menghalanginya. Sehingga pada saat nantinya, pihak yang berwenang dapat mempertimbangkan hal-hal yang harus dilakukan dalam menjaga pesisir pantai di Pantai Kualo ini. Berdasarkan hal ini, penelitian tentang peramalan perubahan garis pantai di Pantai kualo Kota Bengkulu dalam jangka waktu tertentu perlu dilakukan . Tujuan dari penelitian ini yaitu menganalisis besarnya transpor sedimen yang terjadi di Pantai Kualo Bengkulu dan memprediksi perubahan garis pantai dalam jangka waktu 10 tahun di Pantai Kualo Bengkulu. Penelitian ini dilakukan dengan menghitung transpor sedimen yang masuk dan keluar pesisir pantai dengan membagi pantai menjadi 10 sel (pias) sepanjang pantai $500 \mathrm{~m}$ dengan panjang $50 \mathrm{~m}$ pada setiap sel (pias) ditambah satu pias sebagai titik acuan. Penelitian yang dilakukan menghasilkan besarnya transpor sedimen dan perubahan garis pantai.
\end{abstract}

Kata kunci: transpor sedimen, perubahan garis pantai, pantai Kualo

\begin{abstract}
Bengkulu Province is one of the areas with the longest beaches in Indonesia. In general, the condition of the beach in Bengkulu has suffered a lot of damage in the form of abrasion and sedimentation. Changes in coastline are caused by natural and/or human factors. Geographically, Kualo Beach is located in the western part of Sumatra Island which is directly facing the Indian Ocean. This means that the entire west bank is an open sea area with few islands blocking it. So that in the future, the authorities can consider things to do in guarding the coast in Kualo Beach. Based on this, research on forecasting changes in the coastline in kualo Beach, Bengkulu city in a certain period of time needs to be done. The purpose of this study is to analyze the amount of sediment transport that occurs in Kualo Beach Bengkulu and predict changes in the coastline in a period of 10 years in Kualo Beach Bengkulu. This study was conducted by calculating the transport of sediment in and out of the coast by dividing the beach into 10 cells (pias) along the coast of $500 \mathrm{~m}$ with a length of $50 \mathrm{~m}$ in each cell (pias) plus one pias as a reference point. The research resulted in the magnitude of sediment transport and changes in the coastline.
\end{abstract}

Keywords : sediment transport, shoreline changes, Kualo beach 


\section{PENDAHULUAN}

Provinsi Bengkulu merupakan salah satu daerah dengan pantai terpanjang di Indonesia. Secara umum keadaan pantai di Bengkulu telah banyak mengalami kerusakan berupa abrasi dan sedimentasi. Garis pantai merupakan batas pertemuan antara darat dan laut yang dapat mengalami perubahan dari waktu ke waktu sejalan dengan kejadian alam seperti aktivitas gelombang, angin, pasang surut dan arus serta sedimentasi, erosi/longsor maupun penurunan dan pengangkatan material penyusun pantai. Gelombang laut bisa dibangkitkan oleh angin (gelombang angin), gaya tarik menarik matahari,dan bulan (pasang surut), letusan gunung berapi, atau gempa di laut (tsunami), kapal yang bergerak dan sebagainya. Kecepatan angin memungkinkan penyebab terjadinya fenomena alam yaitu erosi, abrasi dan sedimentasi di sepanjang pantai (Triatmojo 1999).

Secara geografis, Pantai Kualo terletak di bagian Barat Pulau Sumatera yang berhadapan langsung dengan Samudera Hindia. Ini berarti, seluruh tepian barat merupakan daerah laut lepas dengan sedikit pulau yang menghalanginya. Sehingga pada saat nantinya, pihak yang berwenang dapat mempertimbangkan hal-hal yang harus dilakukan dalam menjaga pesisir pantai di Pantai Kualo ini. Berdasarkan hal tersebut, penelitian tentang peramalan perubahan garis pantai di Pantai kualo Kota Bengkulu dalam jangka waktu tertentu perlu dilakukan. Tujuan dari penelitian ini adalah untuk menganalisa besarnya transpor sedimen yang terjadi di Pantai Kualo Bengkulu, serta memprediksi perubahan garis pantai dalam jangka waktu 5 tahun..

\section{METODE PENELITIAN}

\section{Lokasi penelitian}

Lokasi penelitian tentang Pemodelan Transpor Sedimen Pantai Kualo Kota Bengkulu dapat dilihat pada Gambar 1.

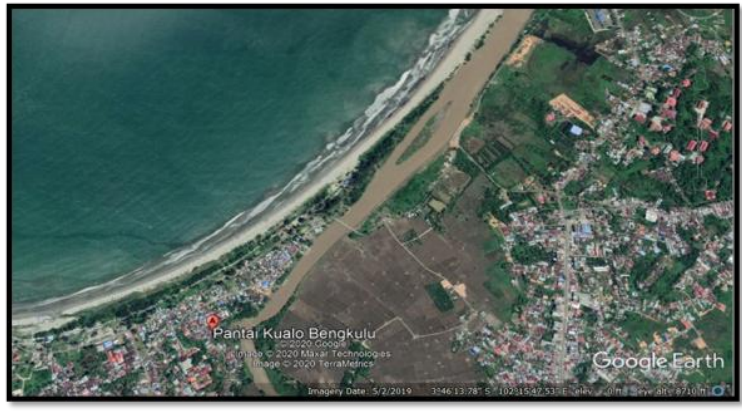

Gambar 1. Lokasi penelitian (Google Earth,2020)

\section{Metode pengumpulan data}

Data yang digunakan dalam penelitian ini adalah data primer dan data sekunder. Data primer merupakan data yang langsung didapatkan dari lokasi yang ditinjau dengan melakukan survei dan pengujian di laboratorium. Sedangkan data sekunder merupakan data yang telah tersedia dari berbagai sumber.

\section{HASIL DAN PEMBAHASAN}

\section{Analisis data angin}

Data angin diperoleh dari BMKG Kelas 1 Pulau Bai selama 10 tahun (2011-2020). Hasil dari pengolahan data tersebut didapatkan arah angina dominan pada lokasi penelitian adalah arah barat yang ditunjukkan pada Gambar 2.

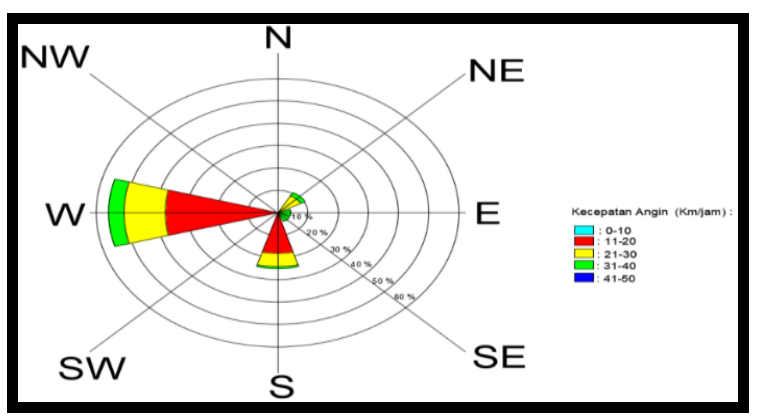

Gambar 2. Diagram Mawar Angin (Wind Rose)

\section{Analisis data pasang surut}

Data pasang surut didapatkan dari TNI Angkatan Laut Kota Bengkulu selama 4 tahun (2016-2020). Hasil dari pengolahan data pasang surut ini didapatkan tinggi muka air (d) pada lokasi penelitian setinggi $5,5 \mathrm{~m}$. 


\section{Perhitungan Tinggi dan Kedalaman Gelombang Pecah (Hb dan db)}

Ketinggian dan kedalaman gelombang pecah dihitung menggunakan hasil data pengolahan dari BMKG kelas 1 pulau Bai dan juga dari pengolahan data pasang surut yang telah didapat. Hasil dari analisis perhitungan tinggi dan kedalaman gelombang pecah $\left(\mathrm{H}_{\mathrm{b}}\right.$ dan $\left.\mathrm{d}_{\mathrm{b}}\right)$ pada lokasi penelitian didapatkan sebesar $2,871 \mathrm{~m}$ dan $2,469 \mathrm{~m}$.

\section{Perhitungan Transpor Sedimen dan Analisis Perubahan Garis Pantai}

Perubahan garis pantai dapat dianalisis dengan menghitung sedimen yang masuk dan yang keluar dari pantai yang ditinjau. Pada penelitian ini perhitungan transpor sedimen sejajar pantai menggunakan metode Bijker. Pengolahan data transport sedimen dengan menggunakan metode Bijker memperhitungkan jumlah sedimen dasar (Sb) dan sedimen layang (Ss). Hasil sedimen total yang terjadi di Pantai Kualo Kota Bengkulu dapat dilihat di Tabel 1:

Tabel 1. Sedimen Total

\begin{tabular}{|c|c|c|c|}
\hline $\begin{array}{c}\text { Pias } \\
\text { (i) }\end{array}$ & $\begin{array}{c}\mathrm{S}_{\mathrm{b}} \\
\mathrm{m}^{3} / \mathrm{hari}\end{array}$ & $\begin{array}{c}\mathrm{S}_{\mathrm{s}} \\
\mathrm{m}^{3} / \mathrm{hari}\end{array}$ & $\begin{array}{c}\text { Stot (Q) } \\
\mathrm{m}^{3} / \mathrm{hari}\end{array}$ \\
\hline 0 & 2,4014 & 0,245496 & 2,6469 \\
\hline 1 & 4,1829 & 1,480637 & 5,6636 \\
\hline 2 & 3,4658 & 0,793538 & 4,2594 \\
\hline 3 & 2,8271 & 0,411207 & 3,2383 \\
\hline 4 & 3,3808 & 0,731754 & 4,1126 \\
\hline 5 & 2,9123 & 0,452124 & 3,3645 \\
\hline 6 & 2,5715 & 0,304471 & 2,8760 \\
\hline 7 & 3,1680 & 0,592576 & 3,7606 \\
\hline 8 & 4,0573 & 1,336507 & 5,3938 \\
\hline 9 & 3,7625 & 1,039662 & 4,8021 \\
\hline 10 & 3,5931 & 0,893167 & 4,4863 \\
\hline
\end{tabular}

Hasil sedimentasi yang terjadi menjadi landasan untuk memprediksi perubahan garis pantai yang akan terjadi selama 5 tahun ke depan di Pantai Kualo Kota Bengkulu seperti pada lampiran. Grafik perubahan garis pantai Kualo dapat dilihat pada Gambar 3.

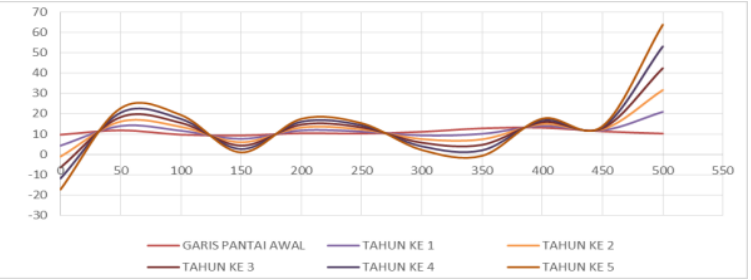

Gambar 3. Perubahan Garis Pantai Selama 5 tahun (2020-2025)

\section{Validasi Model}

Untuk mengethui nilai error yang terjadi dalam perhitungan, dilakukan kontrol error dengan menggunakan rumus Root Mean Square Error (RMSE). Nilai eror dibatasi tidak boleh melebihi $10 \%$ garis pantai awal. Validasi model ini menggunakan hasil perbandingan antara garis pantai eksisting dan garis pantai yang direncanakan (model) seperti pada persamaan (1).

RMSE $=\sqrt{\frac{\sum_{i=1}^{\mathrm{n}}\left(\mathrm{X}_{\text {model }} \mathrm{X}_{\mathrm{obs}}\right)^{2}}{\mathrm{n}}}$

y obs = Data garis pantai dari lapanganY

model $=$ Data garis pantai dari model

$\mathrm{n} \quad=$ Jumlah data

Hasil dari validasi tersebut tidak boleh melebihi $10 \%$ dari garis pantai awal dan yang melebihi $10 \%$ dari garis pantai awal hanya $25 \%$ dari semua data garis pantai

\section{Tabel 2. Validasi model}

\begin{tabular}{|c|c|}
\hline $\begin{array}{c}10 \% \text { Dari Garis } \\
\text { Pantai Awal }\end{array}$ & RMSE \\
\hline 0,9700 & 3,9786 \\
\hline 1,1800 & 0,8620 \\
\hline 0,9700 & 0,4562 \\
\hline 0,9300 & 0,3344 \\
\hline 1,0400 & 0,2449 \\
\hline 1,0200 & 0,1044 \\
\hline 1,1100 & 0,3422 \\
\hline 1,2800 & 1,1671 \\
\hline 1,3100 & 0,1531 \\
\hline 1,1300 & 0,0436 \\
\hline
\end{tabular}

Hasil validasi pemodelan garis pantai menggunakan Metode Bijker menunjukkan 
bahwa semua pias masuk kedalam persyaratan validasi.

\section{Batimetri dan Garis Pantai}

Peta batimetri atau kedalaman laut didapatkan dari website BATNAS DEMNAS. Data batimetri dari BATNAS dikonversi menggunakan software Global Mapper untuk menampilkan garis kontur topografi dari peta tersebut.

\section{Pemodelan Perubahan Garis Pantai}

Pemodelan perubahan garis pantai dimulai pada tahun 2020 sebagai data awal garis pantai. Pemodelan yang dilakukan pada penelitian ini menggunakan software $C E D A S$ versi 4.0. Tampilan batimetri pada pemodelan gelombang terhadap garis pantai berupa arah dan tinggi gelombang yang dapat dilihat pada Gambar 4.

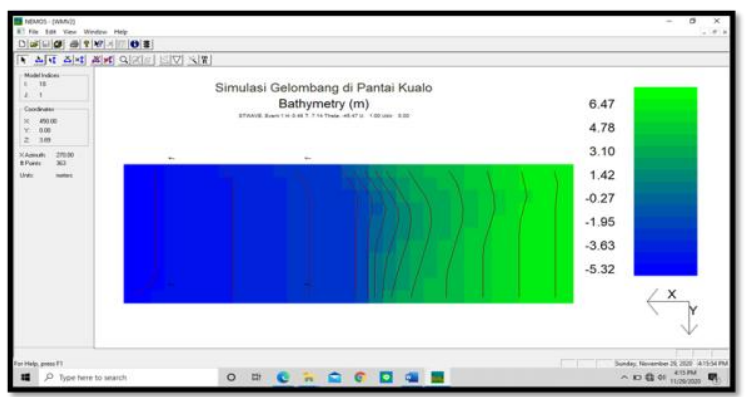

Gambar 4 Hasil Pemodelan Gelombang pada WMV

\section{Model GENESIS}

GENESIS adalah model matematik untuk menghitung perubahan garis pantai akibat adanya serangan gelombang, adanya perubahan struktur bangunan pantai seperti adanya groin, jeti, tembok laut, pemecah gelombang dan lain-lain. Dalam pemodelan garis pantai pada penelitian ini dilakukan prediksi perubahan garis pantai Kualo 5 tahun kedepan (2020-2025) dan 5 tahun kebelakang sebagai validasi.

\section{Hasil Pemodelan Perubahan Garis Pantai}

Hasil pemodelan perubahan garis pantai Kualo 5 tahun kedepan (2020-2025) dan 5 tahun kebelakang sebagai validasi. pada program GENESIS akan tergambarkan melalui animasi model, grafik, dan data perubahan koordinat garis pantai.

Waktu pemodelan yang dipilih untuk perubahan garis pantai 5 tahun dilakukan mulai tanggal 01 November 2020 sampai dengan 28 Desember 2025. Perbandingan animasi model GENESIS pada garis pantai awal dan setelah simulasi dapat dilihat pada Gambar 5.
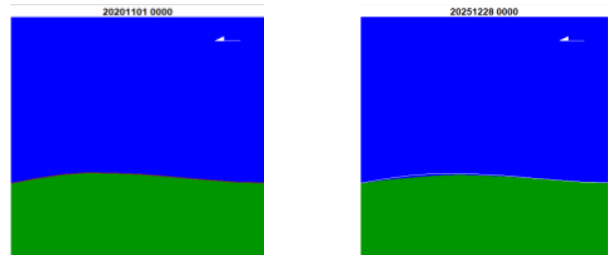

Gambar 5. Pemodelan Perubahan Garis Pantai Kualo 5 Tahun

Untuk melihat gambar perubahan garis pantai yang lebih jelas berikut adalah grafik perbandingan perubahan garis pantai dalam jangka waktu 5 tahun dapat dilihat pada Gambar 6.

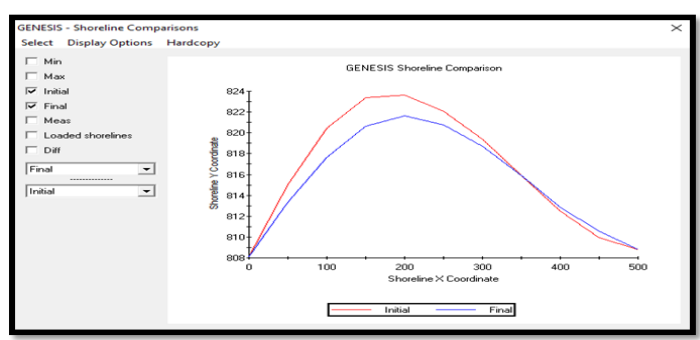

Gambar 6. Grafik Perbandingan Garis Pantai 5 Tahun

\section{Validasi garis pantai 5 tahun sebelumnya}

Validasi perubahan garis pantai dilakukan untuk melihat akurasi dari running program GENESIS. Waktu pemodelan yang dipilih untuk perubahan garis pantai 5 tahun dilakukan mulai tanggal 01 Januari 2015 sampai dengan 01 November 2020. Perbandingan animasi model GENESIS pada garis pantai awal dan setelah simulasi dapat dilihat pada Gambar 7. 

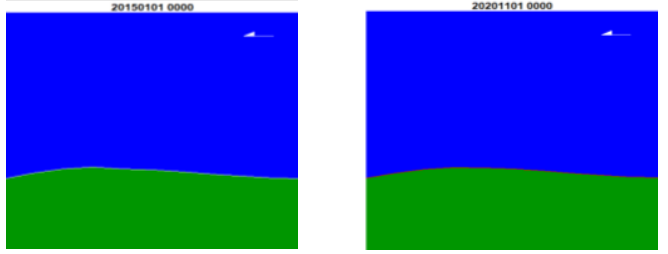

Gambar 7. Validasi Pemodelan Perubahan Garis Pantai 5 Tahun Sebelumnya

\section{Analisa Hasil Pemodelan Perubahan Garis Pantai}

Hasil pemodelan berupa pengurangan garis pantai yaitu abrasi dengan tanda (-) dan penambahan garis pantai yaitu sedimentasi/akresi dengan tanda (+). Perubahan garis pantai setiap jangka waktu mempunya nilai yang berbeda. Hasil simulai garis pantai mengalami perubahan di setiap grid $50 \mathrm{~m}$ sepanjang garis pantai. Nilai perubahan garis pantai dapat dilihat pada Tabel 3

Tabel 3 Nilai Perubahan Garis Pantai

\begin{tabular}{|c|c|c|c|c|c|c|}
\hline \multirow{2}{*}{ Grid } & \multicolumn{2}{|c|}{ Simulasi 2015-2020 } & \multicolumn{2}{c|}{ Simulasi 2020-2025 } \\
\cline { 2 - 7 } & Awal & Akhir & Selisih & Awal & Akhir & Selisih \\
\hline 0 & 808,096 & 808,096 & 0,000 & 808,096 & 808,096 & 0,0002 \\
\hline 50 & 815,922 & 815,030 & $-0,892$ & 815,030 & 813,380 & $-1,650$ \\
\hline 100 & 821,777 & 820,468 & $-1,309$ & 820,468 & 817,674 & $-2,794$ \\
\hline 150 & 824,710 & 823,368 & $-1,342$ & 823,368 & 820,628 & $-2,740$ \\
\hline 200 & 824,090 & 823,636 & $-0,454$ & 823,636 & 821,623 & $-2,013$ \\
\hline 250 & 822,313 & 822,041 & $-0,272$ & 822,041 & 820,732 & $-1,309$ \\
\hline 300 & 819,524 & 819,415 & $-0,109$ & 819,415 & 818,720 & $-0,695$ \\
\hline 350 & 815,913 & 815,913 & 0,000 & 815,913 & 815,913 & 0,0005 \\
\hline 400 & 812,344 & 812,496 & 0,152 & 812,496 & 812,884 & 0,388 \\
\hline 450 & 809,666 & 809,938 & 0,272 & 809,938 & 810,550 & 0,612 \\
\hline 500 & 808,798 & 808,798 & 0,000 & 808,798 & 808,798 & 0,000 \\
\hline
\end{tabular}

1. Untuk memperoleh data yang lebih spesifik dan lebih akurat diperlukan perpanjangan lokasi yang ditinjau dan jarak antar pias diperkecil.

Pada pengolahan data pemodelan perubahan garis pantai pada program GENESIS diperlukan ketelitian untuk mencegah kegagalan pada proses running data.

Perlu dibangun bangunan pantai di kawasan Kualo untuk mencegah sedimentasi yang semakin besar. Perlu dilakukan penelitian lanjutan tentang perubahan garis pantai Kualo.

Berdasarkan Tabel 3 pada tahun 2025 terlihat pengurangan garis pantai (abrasi) bertanda negatif (-) pada grid 150 sebesar $1,342 \mathrm{~m}$, sedangkan penambahan garis pantai (sedimentasi) bertanda positif (+) pada grid 450 sebesar $0,272 \mathrm{~m}$.

\section{KESIMPULAN}

1. Hasil perhitungan sedimentasi menunjukkan bahwa sedimen total 
Besperi et.al

\section{DAFTAR NOTASI}

$\mathrm{Kr} \quad$ : Koefisien refraksi

$\alpha$ : Deviasi pada kedua sisi dari arah angin, dengan menggunakan pertambahan $6^{\circ}$ sampai sudut sebesar $42^{\circ}$ pada kedua sisi dari arah angin.

$\alpha 0$ : Sudut arah datang gelombang pada arah angin terbanyak

$\mathrm{Hb}$ : Tinggi gelombang pecah

$\mathrm{db}$ : kedalaman gelombang pecah

Qs : Angkutan sedimen sepanjang pantai (m3/hari)

\section{DAFTAR PUSTAKA}

CERC. 1984. Shore Protection Manual Volume I. US Army Coastal Engineering Research Center: Washington.

Komar, P.D., 1984, CRC Handbook of Coastal Processes and Erosion. CRC, Florida.

Triatmodjo, B. 1999. Teknik Pantai. Beta Offset: Yogyakarta.

Triatmodjo, B. 2012. Perencanaan bangunan Pantai. Beta Offset: Yogyakarta. 